Article

\title{
Bio-Ecological Traits of Western Tubenose Goby Proterorhinus semilunaris (Heckel, 1837): A Key to Understand Its Invasion Success
}

\author{
Gülşah Saç \\ Department of Marine and Freshwater Resources Management, Faculty of Aquatic Sciences, İstanbul University, \\ 34134 İstanbul, Turkey; gulsahsac@gmail.com; Tel.: +90-0555-351-2569
}

Received: 23 March 2019; Accepted: 3 June 2019; Published: 14 June 2019

check for updates

\begin{abstract}
This study aims to contribute to the limited knowledge on the bio-ecological traits of the native Western tubenose goby, Proterorhinus semilunaris, which is considered to invade many inland waters in Europe and North America. During monthly sampling surveys from March 2012 to June 2013, the species was collected from the four stations in the Istranca River (Turkey) by electrofishing. The standard length and body weight of 310 samples varied between 1.4-6.1 cm and 0.08-7.09 g, respectively. The sex ratio of female to male was found to be 1.7:1.0, with a significant difference. The values of the exponent $b$ in the length-weight relationship were approximately 3 for females, males, and all individuals, indicating an isometric growth. The size at first sexual maturity was $2.44 \mathrm{~cm}$ standard length (SL) for females and $2.29 \mathrm{~cm}$ SL for males. Absolute fecundity ranged from 56 to 344 eggs with a mean of 164 eggs. The food composition of the species comprised of 8 major groups: Insecta (Diptera, Ephemeroptera, Plecoptera, Odonata, Trichoptera, Coleoptera), Arachnida, Annelida, Gastropoda, Crustacea, Pisces, plant, and detritus. According to the results of modified index of relative importance (MI) and index of relative importance (IRI), insect and Diptera were the most prevalent prey for this fish. The present study has provided baseline information on the basic biological traits of the fish in its natural habitat for further understanding of this species success of invasion.
\end{abstract}

Keywords: native; growth; reproduction; feeding; invader

\section{Introduction}

The Western tubenose goby, Proterorhinus semilunaris (Heckel, 1837), is one of the Ponto-Caspian gobies, which is native to the Black Sea basin and Maritza and Struma drainages in the eastern Aegean basin [1]. With the opening of Rhine-Main-Danube waterway in 1992, it has extended its non-native range to Western Europe [2]. However, in the early 1990s, it also spread out its ranges as far as the Great Lakes in Northern America due to its transport in ballast water [3]. Today, it is considered as potentially harmful for native fish populations in Europe and Northern America because of its ecological plasticity $[4,5]$. Some traits of this invader species such as wide habitat tolerance (found in lakes, streams, canals, estuaries, and rivers), early sexual maturity (1-2 years), multiple spawning within a season, and variable food spectrum facilitate its rapid colonization of novel habitats [1,6,7]. These traits might also impact on the presence and densities of native fish due to its competition for food and reproduction.

Proterorhinus semilunaris is one of the native gobiid species in the fish fauna of Turkish inland waters [1]. Only a few studies have recently been carried out in Turkish part of its native range to fill the gap in knowledge on its bio-ecology, including the length-weight relationship, diel activity, trophic ecology, age structure, somatic growth, and reproductive characteristics of the species [8-11]. 
In order to assess the invasion success of the species in its non-native range, it is important to present the basic data on the bio-ecological traits (such as length-weight model, condition, sex ratio, length at first maturity, fecundity, and diet) of those species in their native area. The objective of the present study was therefore to characterize P. semilunaris in growth, reproduction, and feeding to contribute to the limited knowledge of the life-history traits of the species from the native range.

\section{Materials and Methods}

\subsection{Study Area}

The study area is the Istranca River, located in the northwest of İstanbul, Turkey. It is an endorheic stream and flows into the Lake Durusu (Figure 1). The River flows through the forested area at a low altitude along the Istranca Mountains, and its watershed covers approximately $450 \mathrm{~km}^{2}$. The catchment area of the river is characterised by croplands and forestlands with a few small villages in the rural area. Domestic and agriculture pollution and animal waste influence the river. The other fish species living in the river are Cobitis pontica, Alburnoides tzanevi, Alburnus istanbulensis, Barbus cyclolepis, Carassius gibelio, Gobio bulgaricus, Leucaspius delineatus, Petroleuciscus borysthenicus, Phoxinus strandjae, Rhodeus amarus, Rutilus frisii, R. rutilus, Squalius cephalus, Vimva vimba, Esox lucius, Knipowitschia caucasica, Ponticola cf. eurycephalus, Babka gymnotrachelus, and Neogobius melanostomus. The sampling surveys were carried out at four tributaries along the river:

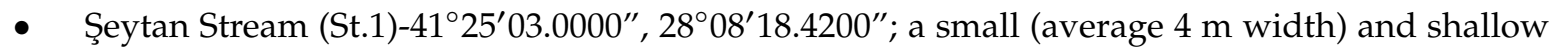
(average $16 \mathrm{~cm}$ depth) stream with stony (cobbles) substrate.

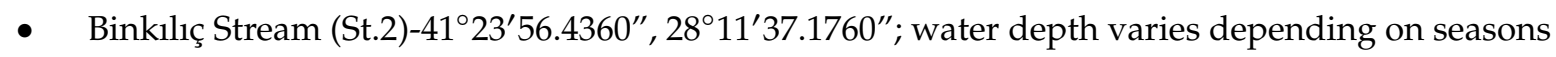
$(15-65 \mathrm{~cm})$, and the substrate is mostly stony (cobbles and gravel).

- Karamandere Stream (St.3)-41 $22^{\prime} 45.1200^{\prime \prime}, 2^{\circ} 17^{\prime} 45.9600^{\prime \prime}$; the deepest (average $54 \mathrm{~cm}$ ) station, and the substrate is mostly stony (boulders and cobbles) with leaf detritus.

- Karacaköy Stream (St.4)- $41^{\circ} 23^{\prime} 58.0560^{\prime \prime}, 28^{\circ} 23^{\prime} 00.6720^{\prime \prime}$; the stream bed and depth vary depending on seasons (3-16 m width and 11-45 cm depth), and the substrate is mostly sandy (rarely boulders and cobbles) (Figure 1).

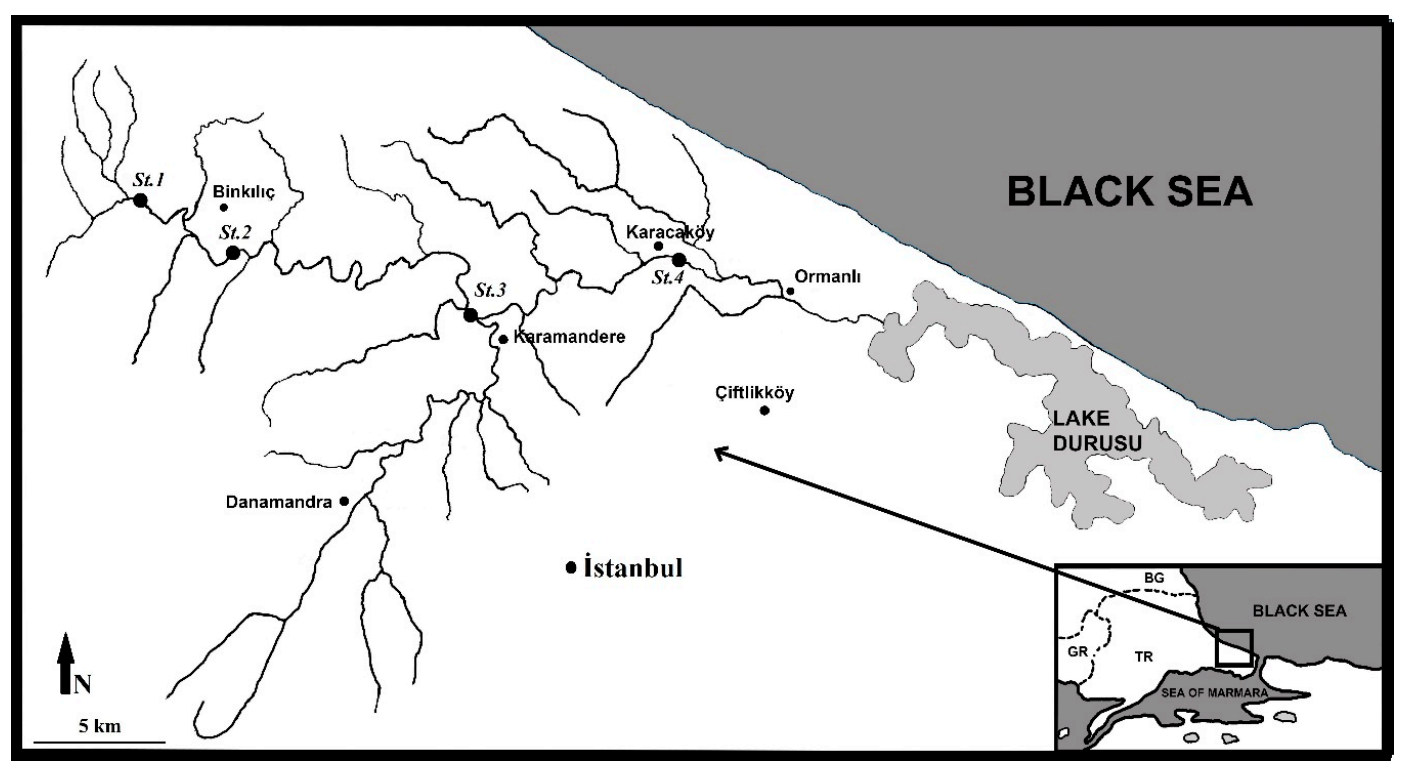

Figure 1. Map of the study area (Istranca River, Lake Durusu Basin, Turkey).

\subsection{Sampling}

Fish samples were monthly collected by a portable electroshocker (SAMUS 725-G and SAMUS 725-M; frequency 50-55 Hz; 30-70 cm fishing depth) from the stream between March 2012 and June 
2013. Sampling was conducted by wading upstream during daylight. In each sampling station, an approximately $50 \mathrm{~m}$ stream section was sampled. After capture, fish samples were killed with an overdose of clove oil and then transferred to the laboratory in the cold. In the laboratory, for each individual, standard length (SL) was measured to the nearest $0.1 \mathrm{~cm}$, and total body weight (W) was weighed on a digital balance with a $0.01 \mathrm{~g}$ accuracy (Precisa XB 220A). Gonads were sexed by macroscopic or microscopic examination. The chi-square test was used to test the observed sex ratio (females to males) against theoretical ratio 1:1 [12].

\subsection{Growth Type}

The length-weight relationship (LWR) was calculated using the equation: $\mathrm{W}=a \mathrm{~L}^{b}$, where $\mathrm{W}$ is the total weight $(\mathrm{g}), \mathrm{L}$ is the standard length $(\mathrm{cm}), a$ and $b$ are regression parameters $[13,14]$. The equation $\left(\mathrm{W}=a \mathrm{~L}^{b}\right)$ was converted into the natural logarithmic form $(\ln W=\ln a+b \ln L)$, and parameters $a$ (regression intercept) and $b$ (slope) were calculated by the regression analysis [15]. To determine the growth type (isometry or allometry) of the species, ninety-five percent confidence limits $(95 \% \mathrm{Cl})$ of parameter $b$ was estimated by the equation: $95 \% \mathrm{Cl}=\mathrm{x} \pm\left(\mathrm{t}_{0.05} \times \mathrm{SE}\right)(\mathrm{x}: b ; \mathrm{t}$ : table value of $\mathrm{t}(t$-test at 95\% confidence)); SE: standard error value of $b$ ) [15].

\subsection{Reproduction}

The gonads were detached from the fish and weighed to the nearest $0.0001 \mathrm{~g}$. To determine the spawning period of the species, gonadosomatic index (GSI) was calculated as the percentage of the ratio between gonad weight $(\mathrm{G})$ and total body weight $(\mathrm{W})$ [16]. For the estimation of mean length at $50 \%$ maturity $\left(\mathrm{L}_{\mathrm{m}}\right)$, a logistic function was fitted to the proportion of the mature individuals by size class using non-linear regression. The function used for calculating length at first maturity was: $\mathrm{P}=1 /\left\{1+\exp \left[-r \times\left(\mathrm{L}-\mathrm{L}_{\mathrm{m}}\right)\right]\right\}$, where $\mathrm{P}$ is the proportion of mature individuals in each size class, $r$ ( $-b$ slope) is a parameter controlling the slope of the curve and $\mathrm{L}_{\mathrm{m}}$ is the size at $50 \%$ maturity [15]. The absolute fecundity (F) was determined as the number of ripe eggs in each ovary. Egg diameters were measured from ripe eggs (30 eggs in each female) using a millimetric binocular (Nikon SMZ 745T). Relative fecundity (RF) was estimated as the ratio between absolute fecundity (F) and body length and weight (SL and W). The relationships between fecundity and fish length were calculated by regression analysis; $\mathrm{F}=a \mathrm{~L}^{b}$, where $\mathrm{F}$ is fecundity, $\mathrm{L}$ is the standard length $(\mathrm{cm}), a$ is the regression constant, and $b$ is the regression coefficient.

\subsection{Feeding}

To determine the diet composition and feeding strategy of P. semilunaris, a total of 186 fish specimens (St.1: 35 specimens; St.2: 35 specimens; St.3: 48 specimens; St.4: 68 specimens) was examined. The digestive tracts were removed and fixed in $4 \%$ formaldehyde solution until analyses. The vacuity index $(\mathrm{VI} \%)$ of the species for each station was estimated as a percentage of empty digestive tracts: $\mathrm{VI} \%=\left(\mathrm{N}_{\mathrm{e}} / \mathrm{N}_{\mathrm{t}}\right) \times 100, \mathrm{~N}_{\mathrm{e}}$ is the number of the empty digestive tracts, $\mathrm{N}_{\mathrm{t}}$ is the total number of examined digestive tracts [17].

The prey items were identified to the lowest possible taxonomic level using a binocular microscope (Nikon SMZ 745T) and then grouped. Each taxonomic group was counted individually, oven dried at $80{ }^{\circ} \mathrm{C}(2-4 \mathrm{~h})$, and weighed to the nearest $0.0001 \mathrm{~g}$. The modified index of relative importance (MI\%) of each uncountable prey items (major groups such as plant, detritus, etc.) and the index of relative importance (IRI\%) of each countable prey items (insects groups) were estimated as follows: $\mathrm{MI} \%=[(\mathrm{F} \% \times \mathrm{W} \%) / \Sigma(\mathrm{F} \% \times \mathrm{W} \%)] \times 100$, and $\mathrm{IRI} \%=[((\mathrm{N} \%+\mathrm{W} \%) \times \mathrm{F} \%) / \Sigma((\mathrm{N} \%+\mathrm{W} \%) \times \mathrm{F} \%)] \times 100$, where $\mathrm{F} \%$ is the percentage of frequency of occurrence [(number of digestive tracts containing a food item/total number of digestive tracts with food) $\times 100$ ], $\mathrm{N} \%$ is a numerical percentage and $\mathrm{W} \%$ is the percentage of gravimetric composition $[18,19]$. Temporal and spatial differences in the diet spectrum of the species were determined. 
Niche breadth of the species was estimated using Levins' $(\mathrm{B})$ and Levins' standardized $\left(\mathrm{B}_{\mathrm{A}}\right)$ indices $[20,21]$. Levins' $B$ and standardized $B_{A}$ are minimal when all the individuals occur in only one resource state (minimum niche breadth, maximum specialization). The range of $B$ is from 1 to $n$, where $n$ is the total number of resource states and $B_{A}$ varies between 0 (species consume a single food item) and 1.0 (species exploits available items in equal proportion) [22]. Values of $\mathrm{B}_{\mathrm{A}}$ are considered high when higher than 0.6, intermediate, when between 0.4 and 0.6, and low when below 0.4 [23].

To interpret the prey importance in digestive tract contents data and to assess the feeding strategy of the species studied, the modified Costello's [24] diagram method was used [25]. In this method, the prey-specific abundance $\left(\mathrm{P}_{i} \%\right)$ was plotted against the frequency of occurrence $(\mathrm{F})$. The percent abundance, increasing along the diagonal from the lower left to the upper right corner, provides a measure of prey importance (with dominant prey at the upper, and rare or unimportant prey at the lower end) and represents the feeding strategy of the predator in terms of generalization or specialization (most points at the bottom state the generalization and, most points at the top of the diagram state the specialization). The calculation of the prey-specific abundance was carried out by the formula: $\mathrm{P}_{i}=\left(\sum \mathrm{S}_{i} / \sum \mathrm{S}_{t i}\right) \times 100$, where $\mathrm{P}_{i}$ is the prey-specific abundance of prey $i, \mathrm{~S}_{i}$ is the digestive tract content (volume, weight or number) comprised of prey $i$, and $S_{t i}$ is the total digestive tract content in only those predators with prey $i$ in their digestive tract.

The Excel software was used in the evaluation of growth, reproduction, and feeding data.

\section{Results}

\subsection{Biometrics}

A total of 310 P. semilunaris specimens was captured from the Istranca River (St.1: 63 specimens, St.2: 68 specimens, St.3: 66 specimens, St.4: 113 specimens). The standard length and body weight of the specimens varied between $1.4-6.1 \mathrm{~cm}$ and $0.08-7.09 \mathrm{~g}$, respectively (Table 1 ). The sex ratio of female to male was found to be 1.7:1.0 with significant difference $\left(x^{2}=16.8 ; p<0.05\right)$.

Table 1. The descriptive statistics and estimated parameters of length-weight relationships of $P$. semilunaris ( $n$, number of individuals; $a$, intercept; $b$, slope; $95 \% \mathrm{Cl}$ : 95\% confidence limit; $r^{2}$, coefficient correlation).

\begin{tabular}{|c|c|c|c|c|c|c|c|c|c|c|}
\hline \multirow[t]{2}{*}{ Sex } & \multirow[t]{2}{*}{$n$} & \multicolumn{2}{|c|}{ Standard Length (SL, cm) } & \multicolumn{2}{|c|}{ Body Weight (W, g) } & \multicolumn{2}{|c|}{$\begin{array}{l}\text { Regression } \\
\text { Parameters }\end{array}$} & \multirow{2}{*}{$\begin{array}{c}95 \% \mathrm{Cl} \text { of } \\
a\end{array}$} & \multirow{2}{*}{$\begin{array}{c}95 \% \mathrm{Cl} \text { of } \\
b\end{array}$} & \multirow[t]{2}{*}{$r^{2}$} \\
\hline & & Mean \pm SD & Min.-Max. & Mean \pm SD & Min.-Max. & $a$ & $b$ & & & \\
\hline Male & 90 & $3.9 \pm 0.7$ & $2.3-6.0$ & $1.83 \pm 1.22$ & $0.33-7.09$ & 0.025 & 3.037 & $0.021-0.030$ & $2.915-3.158$ & 0.953 \\
\hline All Ind. & 310 & $3.6 \pm 0.9$ & $1.4-6.1$ & $1.57 \pm 1.05$ & $0.08-7.09$ & 0.027 & 3.011 & $0.025-0.029$ & $2.956-3.065$ & 0.975 \\
\hline
\end{tabular}

\subsection{Growth}

Length-weight relationship of $P$. semilunaris was calculated for females, males and all individuals as $\ln \mathrm{W}=-3.714+3.109 \times \operatorname{lnSL}, \ln \mathrm{W}=-3.677+3.037 \times \operatorname{lnSL}$ and $\ln \mathrm{W}=-3.605+3.011 \times \ln \mathrm{l} \mathrm{L}$, respectively (Table 1). In terms of growth type, the results showed that the population had isometry $(b=3)$.

\subsection{Reproduction}

According to the gonadosomatic index (GSI), the onset of the spawning in females and males were different. GSI had the highest values (11.6 and 12.4) in May (2012 and 2013) for females, while it had the highest values (2.4 and 6.5) in April (2012 and 2013) for males. However, the lowest values (0.2 and 0.1) of the GSI was observed in August (2012) for both sexes. The spawning period lasted from April to July, and the main spawning activity occurred in May and June (Figure 2). In 2012, the spawning activity finished in July, and no individual carrying eggs ready for spawning was found. 


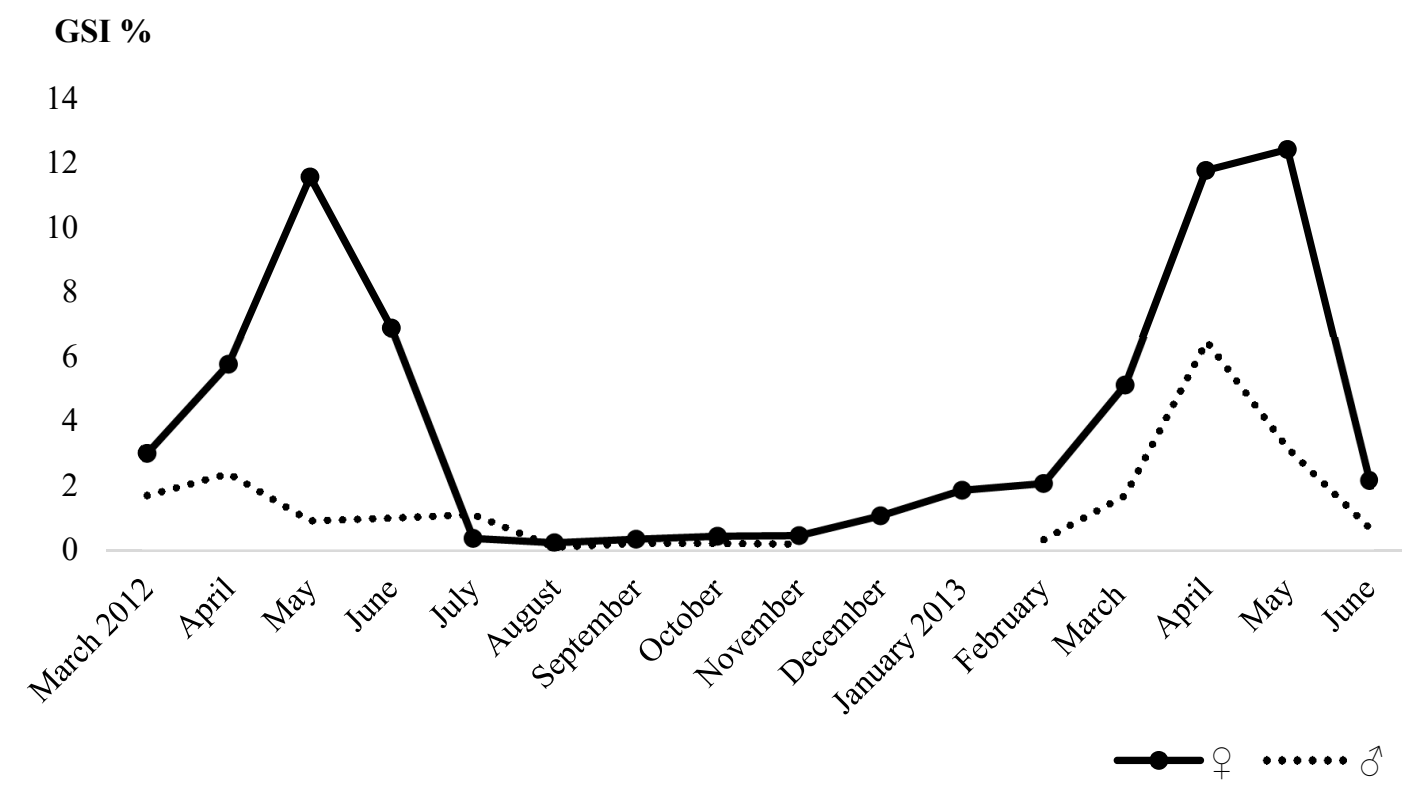

Figure 2. The monthly variation in the gonadosomatic index (GSI) of both female and male P. semilunaris in the Istranca River.

For estimating the fecundity of the species, a total of 53 specimens captured in April and May (both in 2012 and 2013) was used. Mean absolute fecundity in mature female was 164.3 eggs $(\mathrm{SD}=69.9)$, ranging from 56 eggs $(3.1 \mathrm{~cm} \mathrm{SL})$ to 344 eggs $(5.0 \mathrm{~cm} \mathrm{SL})$. The absolute fecundity and body length relationship were positively correlated; fecundity-length relationship was $\mathrm{F}=2.469 \times \mathrm{SL}^{3.042}$ $\left(r^{2}=0.885\right)$. Mean relative fecundity was calculated as $40.9 \mathrm{eggs} \cdot \mathrm{cm}^{-1}(\mathrm{SD}=13.3)$ (ranged from 18.1 to $\left.71.6 \mathrm{eggs} \cdot \mathrm{cm}^{-1}\right)$ and $87.2 \mathrm{eggs} \cdot \mathrm{g}^{-1}(\mathrm{SD}=13.8)\left(\right.$ ranged from 48.5 to $\left.119.4 \mathrm{eggs} \cdot \mathrm{g}^{-1}\right)$. The average egg diameters were determined as follow; $1.31 \mathrm{~mm}(n$ : 18; range 1.1-1.6 mm) in May 2012; $1.31 \mathrm{~mm}(n$ : 14; range 1.1-1.5 mm) in April 2013; $1.37 \mathrm{~mm}(n: 18$; range 1.1-1.6 mm) in May 2013. The size at first maturity $\left(\mathrm{L}_{m}\right)$, where $50 \%$ of the individuals had attained gonad development, was $2.44 \mathrm{~cm}$ SL for females and $2.29 \mathrm{~cm}$ SL for males.

\subsection{Feeding}

The vacuity index $(\mathrm{VI} \%)$, Levins' niche breadth $(\mathrm{B})$, and standardized niche breadth $\left(\mathrm{B}_{\mathrm{A}}\right)$ values of the species for each station were given in Table 2.

Table 2. The vacuity index (VI\%), Levins' niche breadth (B), and standardized niche breadth $\left(\mathrm{B}_{\mathrm{A}}\right)$ values of $P$. semilunaris for each station in the Istranca River.

\begin{tabular}{ccccc}
\hline Indices & $\begin{array}{c}\text { Şeytan Stream } \\
\text { (St.1) }\end{array}$ & $\begin{array}{c}\text { Binkılıç Stream } \\
\mathbf{( S t . 2 )}\end{array}$ & $\begin{array}{c}\text { Karamandere } \\
\text { Stream (St.3) }\end{array}$ & $\begin{array}{c}\text { Karacaköy Stream } \\
\text { (St.4) }\end{array}$ \\
\hline VI\% & 29.63 & 36.21 & 31.75 & 13.33 \\
B & 3.28 & 2.29 & 3.14 & 3.66 \\
$\mathbf{B}_{\mathbf{A}}$ & 0.46 & 0.26 & 0.27 & 0.24 \\
\hline
\end{tabular}

The diet spectrum of P. semilunaris consisted of eight major prey groups: Insecta (Diptera, Ephemeroptera, Plecoptera, Odonata, Trichoptera and Coleoptera), plants (terrestrial plants and algae), Annelida, Arachnida (Acari), Gastropoda, Crustacea (Gammarid and Ostracoda), Pisces (eggs and larvae) and detritus. Insects were the most preferred prey item in terms of modified index of relative importance (MI\%) for each station (St.1: 100\%; St.2: 99.88\%; St.3: 99.87\%; St.4: 99.28\%), and the consumed insect groups mostly composed of Diptera (Table 3). Proterorhinus semilunaris on the Istranca River displayed distinct differences in seasonal dietary composition (Table 4). In spring and summer months all the food types were preferred by the fish, but in winter only insect groups were consumed. 
Table 3. The diet composition of $P$. semilunaris for each station ( $n$, number of individuals; IRI (\%), the index of relative importance for countable prey items; MI (\%), the modified index of relative importance for uncountable prey items).

\begin{tabular}{|c|c|c|c|c|c|c|c|c|}
\hline \multirow[t]{2}{*}{ Preys } & \multicolumn{2}{|c|}{$\begin{array}{l}\text { Şeytan Stream (St.1) } \\
\quad(n=35)\end{array}$} & \multicolumn{2}{|c|}{$\begin{array}{c}\text { Binkılıç Stream (St.2) } \\
(n=35)\end{array}$} & \multicolumn{2}{|c|}{$\begin{array}{l}\text { Karamandere Stream (St.3) } \\
\qquad(n=48)\end{array}$} & \multicolumn{2}{|c|}{$\begin{array}{c}\text { Karacaköy Stream (St.4) } \\
\qquad(n=68)\end{array}$} \\
\hline & MI\% & IRI\% & MI\% & IRI\% & MI\% & IRI\% & MI\% & IRI\% \\
\hline Insecta & 100.00 & & 99.88 & & 99.87 & & 99.28 & \\
\hline Diptera & & 86.57 & & 75.53 & & 53.28 & & 95.71 \\
\hline Ephemeroptera & & 12.75 & & 24.45 & & 45.86 & & 2.00 \\
\hline Plecoptera & & 0.35 & & 0.01 & & 0.14 & & 0.19 \\
\hline Trichoptera & & 0.20 & & - & & 0.45 & & 1.50 \\
\hline Odonata & & 0.13 & & - & & 0.28 & & 0.50 \\
\hline Coleoptera & & - & & 0.01 & & - & & 0.11 \\
\hline Pisces & - & & 0.08 & & - & & 0.42 & \\
\hline Crustacea & $<0.01$ & & - & & 0.05 & & 0.12 & \\
\hline Annelida & - & & - & & - & & 0.16 & \\
\hline Arachnida & - & & - & & $<0.01$ & & - & \\
\hline Gastropoda & - & & - & & - & & $<0.01$ & \\
\hline Plant & - & & 0.03 & & 0.01 & & 0.01 & \\
\hline Detritus & - & & - & & 0.06 & & 0.01 & \\
\hline
\end{tabular}

Table 4. Seasonal IRI\% and MI\% values of food types consumed by P. semilunaris in the Istranca River ( $n$, number of individuals; Sp., spring; Su., summer; Au., autumn; Wi., winter).

\begin{tabular}{ccccccc}
\hline $\begin{array}{c}\text { Preys and } \\
\text { Indices }\end{array}$ & $\begin{array}{c}\text { Sp., 2012 } \\
(\boldsymbol{n}=\mathbf{6 4})\end{array}$ & $\begin{array}{c}\text { Su., 2012 } \\
(\boldsymbol{n}=\mathbf{2 3})\end{array}$ & $\begin{array}{c}\text { Au., 2012 } \\
(\boldsymbol{n}=\mathbf{2 1})\end{array}$ & $\begin{array}{c}\text { Wi., 2012 } \\
(\boldsymbol{n}=\mathbf{1 0})\end{array}$ & $\begin{array}{c}\text { Sp., 2013 } \\
(\boldsymbol{n}=\mathbf{6 0})\end{array}$ & $\begin{array}{c}\text { Su., 2013 } \\
(\boldsymbol{n}=\mathbf{8})\end{array}$ \\
\hline IRI\% & & & & & & \\
\hline Diptera & 91.40 & 80.00 & 80.00 & 90.21 & 93.93 & 65.39 \\
Plecoptera & 0.20 & 0.04 & 0.04 & 2.96 & 0.05 & \\
Trichoptera & 0.19 & 18.93 & 18.93 & 1.61 & 0.07 & \\
Odonata & 0.16 & 0.69 & 0.69 & & 0.01 & 24.23 \\
Ephemeroptera & 7.97 & 0.34 & 0.34 & 4.99 & 5.92 & 10.38 \\
Coleoptera & 0.07 & & & 0.24 & 0.02 & \\
\hline MI\% & & & & & & \\
\hline Fish & 0.01 & 0.10 & & & & \\
Detritus & 0.01 & & 0.58 & & & \\
Crustacea & 0.14 & 0.43 & 0.01 & & & \\
Arachnida & $<0.01$ & & 0.11 & & & \\
Annelida & 0.19 & & & & & \\
Plant & & 0.10 & 0.14 & & & \\
Gastropoda & & & 0.02 & & & \\
\hline
\end{tabular}

According to the diagram of the modified Costello graphical method, the species has a generalist feeding strategy (Figure 3). All prey point located in the lower part of the diagrams and in terms of prey importance, Annelida, Pisces, Odonata, Coleoptera, Gastropoda, Crustacea, Arachnida, plant, and detritus presented low values in axis $\left(\mathrm{P}_{i} \%\right.$ and $\left.\mathrm{F}\right)$, displaying evidence of a rare feeding. 


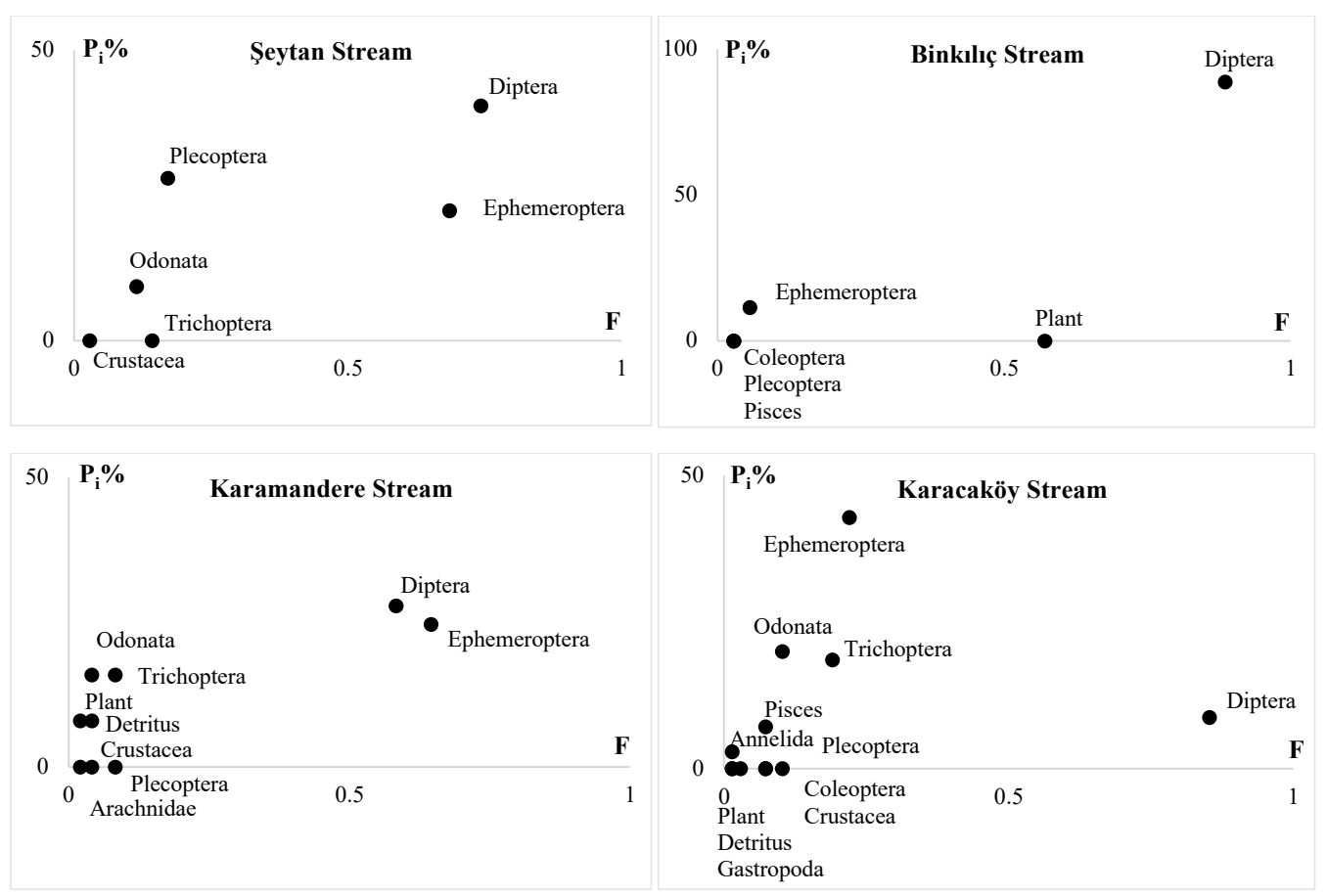

Figure 3. The modified Costello feeding strategy diagrams for P. semilunaris for each station. Prey-specific abundance $\left(\mathrm{P}_{i} \%\right)$ plotted against frequency of occurrence $(\mathrm{F})$ of food items in the diet of the species.

\section{Discussion}

In recent studies on P. semilunaris previously known as Proterorhinus marmoratus [8,26], the $b$ values in the LWRs of P. semilunaris populations in Lake İznik, Lake Durusu (Terkos Dam Lake) and Lake Sapanca were reported as 3.20,3.26 and 2.85, respectively. Top et al. [11] reported that the estimated values of $b$ in İznik, Sapanca, and Uluabat lake populations were all above 3.0, indicating positive allometry. However, the growth type of P. semilunaris in the Istranca River was determined as isometric in the present study-in contrast to the other study [26] conducted in the same basin, which reports positive allometry $(b=3.26)$. This difference may be related to body size, number of individuals, season, food availability, and feeding rate of the species. Additionally, the large habitat tolerance of P. semilunaris $[1,6,7]$ allows it to live in different habitats from estuaries to small streams and great lakes, and this may cause the fish to exhibit different bio-ecological properties in different habitats (e.g., stream vs. lake).

According to the result of the sex ratio, the population is female-biased with a female to male ratio of 1.7:1.0. Another female dominated sex ratio was reported for P. semilunaris population from the Lake İznik [11]. In many fish populations, there is a biased adult sex ratio with important demographic and evolutionary consequences [27-29]. Biasing the sex ratio in rapidly colonizing fish populations towards more females could be an effective process that may enhance population growth and contribute to range expansion.

Changes in GSI over the study period indicate that the spawning season of P. semilunaris started in April and lasted until August. The differences in the highest GSI values of the two sexes (May in females and April in males) may be attributed to fish sizes and numbers. Although in females, the highest GSI value was seen in May (both in 2012 and 2013), it was observed that some individuals had laid their eggs in April. The similarity between the ripe egg diameters measured in April and May has contributed to the opinion that the beginning of the spawning was April. Additionally, this relatively long spawning season determined in the present study is similar to the literature [1,30]. According to Valová et al. [30], this reproductive characteristic represents a distinct advantage when colonising new areas (a major competitive advantage over native fish in the same habitat). 
The fecundity was reported for a non-native P. semilunaris population from the Danube basin ranging from 379 to 628 eggs [30]. The values of fecundity from both the Istranca population (i.e., 56-344 eggs in the present study) and also other native populations [11] showed that the fecundity is lower than the non-native population in the Danube basin [30]. For non-native populations, high fecundity might be expected in terms of their population establishment and growth. Small-bodied species generally tend to mature earlier to increase the reproductive capacity and ability to survive/settle in variable and temporary habitats [31]. Early maturation, as observed for P. semilunaris in the present study ( $\left(9: 2.44 \mathrm{~cm} ; o^{7}: 2.27 \mathrm{~cm}\right.$ ), has also been reported in previous studies [1,11,30]. Further, according to Grabowska and Przybylski [32], many non-native fish species that live in Central Europe, including $P$. semilunaris, tend to mature early and have rather low fecundity but relatively large eggs.

The studies on the diet of $P$. semilunaris $[7,10,33,34]$ recorded that the species is a benthic omnivore, consuming a wide variety of benthic invertebrates (dipterans, ephemeropterans, crustaceans, copepods, ostracods, molluscs, and trichopterans), plants, and occasionally larval fishes. The results of the present study have proved that $P$. semilunaris has a wide food spectrum; however, Diptera larvae, which are a very common group of zoobenthos, are the most important food item in the diet of P. semilunaris as a food generalist. When the temporal change in the food preference of the fish was examined, it was seen that there was a distinct drop in food diversity in the diet over winter, but this increased rapidly in spring months. According to Všetičková et al. [34], the seasonal changes in the diet might be attributable to the requirement of reserves prior to spawning (both rapid replacement of body mass following winter and the need to increase energy) and to a lack of available prey.

While fish consumed 13 different types of food, Levins' indices were calculated to be very low $\left(B_{A}\right.$ was calculated lower than the value 0.4, except St.1 [23]). The high IRI\% values of the dipterans in the diet of P. semilunaris led to a low value of the fish's niche breadth. Therefore, the species has showed a narrow niche breadth and maximum specialization on Diptera. However, the position of Diptera in the diagram (Figure 3) contributes to narrow niche width of the species. The first published data on the food preference of $P$. semilunaris concluded that Crustacea were the most commonly consumed food item [35]. Ghedotti et al. [36] and Charlebois et al. [37] contributed the opinion that besides small crustaceans, P. semilunaris also feed on aquatic insect larvae and ostracods. According to Tarkan et al. [38], the main prey items for the species were represented by Rotifera and detritus in lake ecosystems, where the fish was native (İznik, Sapanca and Uluabat lakes in Turkey). The results of the present study are similar to the results of the studies $[7,39]$ conducted in the non-native distribution range of P. semilunaris (Danube River and Mušov Reservoir); Diptera (mostly chironomids) larvae/pupae are the most dominant food items in the diet of the species. Tarkan et al. [10,38] mentioned that this fish has generalist and highly flexible feeding strategies, and would have relatively large trophic niche sizes, with trophic overlap with other native species that indicate high potential for competitive interactions.

Dietary composition and the percentage of empty digestive tracts of P. semilunaris differed among the stations. Food composition of the species was characterized by relatively low diversity (mainly insect groups, and rarely pisces, crustacean and plant) in the upstream (St.1 and St.2) of the river. Additionally, vacuity index values in these stations were also higher $(29.6 \%$ in St.1 and $36.2 \%$ in St.2). Diptera represented approximately more than $75 \%$ of those taxa found in the insect group. Dipterans are one of the most abundant macroinvertebrate groups in freshwater environments [40]; they have a large spread from upstream to downstream in rivers, and they can also adapt to low water quality. In the Istranca River, downstream stations (St.3 and St.4) are especially influenced by domestic pollution and sewage discharge [41]. These characteristics let Diptera to reach high abundance along the river and are thus easy prey for fish species. However, EPT (Ephemeroptera, Plecoptera, and Trichoptera) species cannot tolerate the presence of pollutants in the water bodies [42] and mostly prefer the headwaters of the river systems. The low values of these insect groups, except Ephemeroptera in the diet of P. semilunaris, may be related to the presence or abundance of them in the Istranca River. According to Dökümcü [43], Ephemeroptera is a more prevalent and abundant group among these 
insects along the Istranca River. Therefore, Ephemeroptera was represented by high values in the diet of the fish after the Diptera. However, the diet of P. semilunaris was characterized by higher diversity in the downstream stations. Especially in the Karacaköy Stream, the species is fed by 12 different food types, and the vacuity index value was estimated as lower. The distribution and abundance of the macroinvertebrate groups along the river systems are the main determinants of the diet of benthic fish species.

In conclusion, the present study has provided baseline information on the bio-ecological traits of P. semilunaris, where there are limited studies about the life-history traits and diet of the species in its native habitats. It is expected that these results can be useful for understanding the success of the colonization of the species in non-native areas.

Funding: This research received no external funding.

Acknowledgments: I would like to thank Müfit Özuluğ and Ali Serhan Tarkan for their significant contributions to this study.

Conflicts of Interest: The author declares no conflict of interest.

\section{References}

1. Kottelat, M.; Freyhof, J. Handbook of European Freshwater Fishes; Publications Kottelat, Cornol and Freyhof: Berlin, Germany, 2007; p. 646.

2. Von Landwüst, C. Expansion of Proterorhinus marmoratus (Teleostei, Gobiidae) into the River Moselle (Germany). Folia Zool. 2006, 55, 107-111.

3. Jude, D.J.; Reider, R.H.; Smith, G.R. Establishment of Gobiidae in the Great Lakes Basin. Can. J. Fish. Aquat. Sci. 1992, 49, 416-421. [CrossRef]

4. Kocovsky, P.M.; Tallman, J.A.; Jude, D.J;; Murphy, D.M.; Brown, J.E.; Stepien, C.A. Expansion of tubenose gobies Proterorhinus semilunaris into western Lake Erie and potential effects on native species. Biol. Invasions 2011, 13, 2775-2784. [CrossRef]

5. Von Kessel, N.; Dorenbosch, M.; Kranenbarg, J.; Van der Velde, G.; Leuven, R.S.E.W. Invasive Ponto-Caspian gobies rapidly reduce the abundance of protected native bullhead. Aquat. Invasions 2016, 11, 179-188. [CrossRef]

6. Manné, S.; Poulet, N. First record of the western tubenose goby Proterorhinus semilunaris (Heckel, 1837) in France. Knowl. Manag. Aquat. Ecosyst. 2008, 389, 3. [CrossRef]

7. Adámek, Z.; Jurajda, P.; Prášek, V.; Sukop, I. Seasonal diet pattern of non-native tubenose goby (Proterorhinus semilunaris) in a lowland reservoir (Mušov, Czech Republic). Knowl. Manag. Aquat. Ecosyst. 2010, 397, 2. [CrossRef]

8. Tarkan, A.S.; Gaygusuz, Ö.; Özulŭ̆, M.; Gürsoy Gaygusuz, Ç.; Saç, G. Length-weight relationships of six freshwater fishes from the small streams flowing into Lake Sapanca, NW Turkey. J. Appl. Ichthyol. 2009, 25, 230-231. [CrossRef]

9. Gürsoy Gaygusuz, Ç.; Tarkan, A.S.; Gaygusuz, Ö. The diel changes in feeding activity, microhabitat preferences and abundance of two freshwater fish species in small temperate streams (Ömerli, İstanbul). Ekoloji 2010, 19, 15-24. [CrossRef]

10. Tarkan, A.S.; Karakuş, U.; Tepeköy, E.G.; Top, N.; Yalçın-Özdilek, Ş.; Partal, N.; Britton, J.R. Trophic interactions of two Ponto-Caspian Gobies in the Turkish part of their native range. Turk. J. Fish. Aquat. Sci. 2018, 18, 1279-1286. [CrossRef]

11. Top, N.; Karakuş, U.; Tepeköy, E.G.; Britton, J.R.; Tarkan, A.S. Plasticity in life history traits of the native Proterorhinus semilunaris suggests high adaptive capacity in its invasive range. Knowl. Manag. Aquat. Ecosyst. 2018, 419, 48. [CrossRef]

12. Zar, J.H. Biostatistical Analysis; Prentice Hall: Englewoods Cliffs, NJ, USA, 1999; p. 663.

13. Le Cren, E.D. The length-weight relationship and seasonal cycle in gonad weight and condition in the perch (Perca fluviatilis). J. Anim. Ecol. 1951, 20, 201-218. [CrossRef]

14. Froese, R. Cube law, condition factor, weight-length relationships: History, meta-analysis and recommendations. J. Appl. Ichthyol. 2006, 22, 241-253. [CrossRef] 
15. King, M. Fisheries Biology, Assessment and Management, 2nd ed.; Blackwell Scientific Publications: Oxford, UK, 2007; p. 381.

16. Ricker, W.E. Computations and interpretation of biological statistics of fish populations. Fish. Res. Bd. Can. Bull. 1975, 191, 1-382.

17. Sarkhanizadeh, A.; Valinassab, T.; Fatemi, M.R. Evaluation of some feeding indices of Atrobucca nibe in the Northern Oman Sea. J. Novel Appl. Sci. 2014, 3, 1268-1274.

18. Hyslop, E.J. Stomach contents analyses-A review of methods and their application. J. Fish Biol. 1980, 17, 411-429. [CrossRef]

19. Hayse, J.W. Feeding habits, age, growth, and reproduction of Atlantic spadefish Chaetodipterus faber (Pisces: Ephippidae) in South Carolina. Fish. Bull. 1990, 88, 67-83.

20. Levins, R. Evolution in Changing Environments; Princeton University Press: Princeton, NJ, USA, 1968 ; p. 132.

21. Hurlbert, S.H. The measurements of niche overlap and some relatives. Ecology 1978, 59, 67-77. [CrossRef]

22. Krebs, C.J. Ecological Methodology; Addison-Wesley Educational Publishers: Menlo Park, CA, USA, 1998.

23. Novakowski, G.G.; Hahn, N.S.; Fugi, R. Diet seasonality and food overlap of the fish assemblage in a pantanal pond. Neotrop. Ichthyol. 2008, 6, 567-576. [CrossRef]

24. Costello, M.J. Predator feeding strategy and prey importance: A new graphical analysis. J. Fish Biol. 1990, 36, 261-263. [CrossRef]

25. Amundsen, P.A.; Gabler, H.M.; Staldvik, F.J. A new approach to graphical analysis of feeding strategy from stomach contents data-Modification of the Costello (1990) method. J. Fish Biol. 1996, 48, 607-614.

26. Tarkan, A.S.; Gaygusuz, Ö.; Acıpınar, H.; Gürsoy, Ç.; Özuluğ, M. Length-weight relationship of fishes from the Marmara region (NW-Turkey). J. Appl. Ichthyol. 2006, 22, 271-273. [CrossRef]

27. Reichard, M.; Polačik, M.; Blažek, R.; Vrtílek, M. Female bias in the adult sex ratio of African annual fishes: Interspecific differences, seasonal trends and environmental predictors. Evolut. Ecol. 2014, 28, 1105-1120. [CrossRef]

28. Székely, T.; Weissing, F.J.; Komdeur, J. Adult sex ratio variation: Implications for breeding systems. J. Evolut. Biol. 2014, 27, 1500-1512. [CrossRef] [PubMed]

29. Field, D.L.; Pickup, M.; Barrett, S.C. Comparative analyses of sex-ratio variation in dioecious flowering plants. Evolution 2012, 67, 661-672. [CrossRef]

30. Valová, Z.; Konečná, M.; Janáč, M.; Jurajda, P. Population and reproductive characteristics of a non-native western tubenose goby (Proterorhinus semilunaris) population unaffected by gobiid competitors. Aquat. Invasions 2015, 10, 57-68. [CrossRef]

31. Hernaman, V.; Munday, P.L. Life-history characteristics of coral reef gobies. II. Mortality rate, mating system and timing of maturation. Mar. Ecol. Prog. Ser. 2005, 290, 223-237. [CrossRef]

32. Grabowska, J.; Przybylski, M. Life-history traits of non-native freshwater fish invaders differentiate them from natives in the Central European bioregion. Rev. Fish Biol. Fish. 2015, 25, 165-178. [CrossRef]

33. French, J.R.P.; Jude, D.J. Diets and diet overlap of nonindigenous Gobies and small benthic native fishes co-inhabiting the St. Clair River, Michigan. J. Great Lakes Res. 2001, 27, 300-311. [CrossRef]

34. Všetičková, L.; Janáč, M.; Vašek, M.; Roche, K.; Jurajda, P. Non-native western tubenose gobies Proterorhinus semilunaris show distinct site, sex and age-related differences in diet. Knowl. Manag. Aquat. Ecosyst. 2014, 414, 10. [CrossRef]

35. Shoryngin, A.A. Food and Feeding Relationships of Fish in the Caspian Sea; Pishchepromizdat: Moscow, Russia, 1952; p. 268. (In Russian)

36. Ghedotti, M.J.; Smihula, J.C.; Smith, G.R. Zebra mussel predation by round gobies in the laboratory. J. Great Lakes Res. 1995, 21, 665-669. [CrossRef]

37. Charlebois, P.M.; Marsden, J.E.; Goettel, R.G.; Wolfe, R.K.; Jude, D.J.; Rudnicka, S. The Round Goby, Neogobius melanostomus (PALLAS), a Review of European and North American Literature. Illinois-Indiana Sea Grant Program and Illinois Natural History Survey; INHS Special Pub.: Champaign, IL, USA, 1997; Volume 20, p. 61.

38. Tarkan, A.S.; Tepeköy, E.G.; Karakuş, U.; Top, N.; Vilizzi, L. Plasticity in the feeding ecology of Native Ponto-Caspian gobies suggests establishment success in their non-native range. Int. Rev. Hydrobiol. 2019, in press. [CrossRef]

39. Adámek, Z.; Andreji, J.; Gallardo, J.M. Food habits of four bottom-dwelling Gobiid species at the confluence of the Danube and Hron Rivers (South Slovakia). Int. Rev. Hydrobiol. 2007, 94, 554-563. [CrossRef] 
40. Keiper, J.B.; Walton, W.E.; Foote, B.A. Biology and ecology of higher Diptera from freshwater wetlands. Annu. Rev. Entomol. 2002, 47, 207-232. [CrossRef] [PubMed]

41. Saç, G.; Özuluğ, M. Effects of environmental variables on the distribution of fish assemblages in an endorheic stream (İstanbul, Turkey). Fresenius Environ. Bull. 2017, 26, 7150-7159.

42. Ab Hamid, S.; Md Rav, C.S. Application of aquatic insects (Ephemeroptera, Plecoptera and Trichoptera) in water quality assessment of Malaysian Headwater. Trop. Life Sci. Res. 2017, 28, 143-162. [CrossRef]

43. Dökümcü, N. Determination of Benthic Macroinvertebrate Fauna of Istranca Stream (Durusu-İstanbul). Master's Thesis, Graduate School of Science and Engineering Biology Department, İstanbul University, Istanbul, Turkey, 2013; p. 69.

(C) 2019 by the author. Licensee MDPI, Basel, Switzerland. This article is an open access article distributed under the terms and conditions of the Creative Commons Attribution (CC BY) license (http://creativecommons.org/licenses/by/4.0/). 